Таблица 5.Случаи нарушения ограничений по перетокам мощностей в контролируемых ЛЭП.

\begin{tabular}{|l|c|c|}
\hline \multirow{2}{*}{\begin{tabular}{l} 
помер \\
\cline { 2 - 3 }
\end{tabular}} & \multicolumn{2}{|c|}{ Суммарная нагрузка энергосистемы, МВт } \\
\hline 1 & 1485 & 1815 \\
\hline 4 & $\mathrm{P}_{6-3}=478,3>470$ & $\mathrm{P}_{6-5}=104,8>95, \mathrm{P}_{0-3}=153,5>150$ \\
\hline 5 & & $\mathrm{P}_{6-3}=479,9>470$ \\
\hline
\end{tabular}

В соответствии с предложенным алгоритмом оптимальный план выбран из числа оставшихся двух - 2-й и 3-й условно-оптимальных планов по критерию минимакса. В результате как оптимальный план получен 3-й условно-оптимальный план, при котором

$\min (i) \max (j) B_{i j}=2344,4$ т.у.т. $/ ч$

$$
P_{1}^{o n}=360 \mathrm{MB}, P_{6}^{o n}=392 \mathrm{MBT}, P_{7}^{o n}=600 \mathrm{MBT}
$$

и из условия баланса активной мощности в энергосистеме

$$
P_{0}^{o n}=1815-360-392-600=463 \mathrm{MBT}
$$

Таким образом, предложенный алгоритм учета ограничений отличается простой процедурой расчета и с достаточной для практических целей точностью.

\section{Заключение}

1. Предложен алгоритм учета ограничений в виде неравенств при оптимальном планировании краткосрочных режимов энергосистем в условиях неопределенности исходной информации.

2. На основе расчетно-экспериментальных исследований выявлена, что предложенный алгоритм обладает простой расчетной процедурой и достаточной для практических целей точностью.
3. Предложенный алгоритм эффективно может применяться для оптимального планирования краткосрочных режимов энергосистем с учетом функциональных ограничений в виде неравенств в условиях частичной неопределенности исходной информации.

\section{Список литературы}

1. Автоматизация диспетчерского управления в электроэнергетике/ Под общей ред. Ю.Н.Руденко и В.А.Семенова. - М.: Изд-во МЭИ, 2000.$648 \mathrm{c}$.

2. Арзамасцев Д.А., Липес А.В., Мызин А.Л. Модели оптимизации развития энергосистем. Москва, Высш. шк., 1987. - 272 с.

3. Гайибов Т.Ш. Методы и алгоритмы оптимизации режимов электроэнергетических систем. Т.: Изд. ТашГТУ, 2014. - 188 с.

4. Гайибов Т.Ш., Жураев М.Э., Узаков Б.А. Алгоритм оптимизации режимов электрических сетей с учетом ограничений в виде неравенств в условиях вероятности исходной информации.// Евразийский Союз Ученых (ЕСУ). Ежемесячный научный журнал. - Москва, 2014. - №4 (часть 5). С. 60-62.

5. Murty P.S.R., Operation and Control in Power Systems. B.S. Publications, Hyderabad, 2008. -410 p.

6. Насиров Т.Х., Гайибов Т.Ш. Теоретические основы оптимизации режимов энергосистем. T.: «Fan va texnologiya», 2014. - 184 c.

\title{
ABOUT THE USAGE OF THE TERM "RELIABILITY" IN TECHNIQUE
}

\section{ABSTRACT}

Galeev A.P. MIIGAiK, Moskow, R.F.,

Geller M.I.

International Informatization Academy, N.Y., U.S.A.,

Nazarova G.S.

Close Corporation LANTEP, Moskow, R.F. DOI: 10.31618/ESU.2413-9335.2019.1.59.10-12

The scope of the term "reliability" in technique is discussed. The examples of the incorrect usage of this term to characterize the results of measurements and observations are presented. The basic terms characterizing the accuracy and the confidence of measurements, observations, established in national and international standards are discusses. It is advisable to use the term "confidence" instead of the term "reliability" for a qualitative characteristic of the correctness of the results of the measurements and the observations. It is possible to speak only about the "metrological reliability" of the measuring equipment, in particular about the preservation of their metrological operability.

Keywords: reliability, confidence, measurement, observation.

In technical and educational literature, including the evaluation of the results of measurements and observations, the term "reliability" is often used incorrectly.
For example, in the book [1, p. 49] we read: "The optimality criterion is the minimum number of measurements to describe the dependence $\boldsymbol{y}(\boldsymbol{x})$ with given reliability (or we get maximum reliability for a given volume of measurements)." 
It is stated in the text [2, p. 5]: "There are tasks of receiving of measurements values with the most reliable final results, followed by the quantitative characteristic of accuracy of these results with some degree of confidence expressed in numerical form." There [2, $p$. $6]$ we read ".. the search of the most reliable value defining value for the results of multiple observations."

Or in the book [3] it says: "...the set of the points $(\mathrm{x}, \mathrm{y})$ gives an initial view of the form of the dependence. For it, reliable determination it is necessarily to have not less than 20 pairs of measurements".

There are many similar examples. However, the use of the term "reliability" to describe the results of the measurements is incorrect and does not comply with the national and international standards used in the field of Metrology.

The origins of this confusion lie in the fact that the theory of reliability and the theory of measurement are both based on the concepts of mathematical statistics. The results of the tests, experiments, measurements, observations and their functions in both cases are treated as the random events [4].

In some cases, incorrect use of the term «reliability» can be also due to inaccuracies in the translation, because in English the word «Reliability" means "the dependability, reliability, strength, confidence (accuracy)" [5].

However, the concept of "reliability" of the technical object and the "confidence" of the results of measurements and tests are essentially different; herewith, in the national standards of the Russian Federation and international standards they are clearly defined.

According to [6] "the reliability is a property of the object to save time within the established vales of all parameters characterizing the ability to perform the required functions within specified regimes and conditions of its use, maintenance, service, storage and transportation". The reliability is a complex property which depends on the purpose of the object and conditions of its use may include reliability, durability, maintainability, serviceability and storage ability or some combination of these properties. In particular, it is possible to speak about the reliability of the measuring equipment].

The confidence of the measurement information according to [7] "is its ability to be correctly perceived and interpreted by far for making management decisions". The confidence of the measurement information depends on the accuracy of measurements - the property reflecting the proximity of measurement results to the accepted reference value of the measured quantity.

The accuracy of measurements can be greater or less, depending on the allocated resources (cost of the measuring instrument, the stabilization of external conditions, etc.). The accuracy should be sufficient to accomplish the task, but no more, because the further increase in accuracy will lead to unnecessary financial costs.

A quantitative measure of the accuracy of measurement results is the systematic and the random errors [8], which enable to estimate the deviation of the measured value of the variable from its reference value in standardized conditions.
Nowadays is widely agreed [9] that after evaluation of all the errors found and the corresponding amendments made to the measurement result, it still remains some uncertainty of the obtained result, i.e. the question in how accurately it corresponds to the measured value.

Under the condition of international market, it is important that the results of measurements obtained in different countries were comparable [9]. To solve this problem, the guidance of ISO/IEC comparatively recently introduced the concept of "measurement uncertainty" which characterizes the dispersion of valued attributed to the measured, based on all available information on its possible variability.

The International Committee of Weights and Measures is supposed to use the term "combined standard uncertainty" for all international comparisons and other works under the auspices of this Committee [9].

Combined standard uncertainty of the measurement result obtained a number of influence quantities, equal to the positive square root of the weighted sum of the variance or covariance of these variables, weighting coefficients which are determined by the dependence of the measurement result from the changes of these values [9].

Thus, to characterize the accuracy of measurements, observations if their statistical evaluation is necessary to use the terms "accuracy", "error", "uncertainty", which correspond to current national and international standards in the field of metrology.

The use of the term "reliability" is not correct, when it is applied to the evaluation of the measurement results. You can only speak about the "metrological reliability" of the measuring equipment, in particular about the preservation of their metrological operability.

As we previously noted [10], the confusion in terminology can lead to consequences, such as when the set of theoretical and practical tasks on the basis of incorrectly formulated indicators (purposes, objective) are used and, what is worse, that financial recourses will be wastefully spent for these purposes.

\section{Literature:}

1. Stremel M. A. Engineer in the laboratory. - M. Metallurgy, 1983, $130 \mathrm{p}$.

2. Bolshakov V. D. Theory of errors of observations, M., Nedra, 1983, 185 p.

3 . The theory of mathematical processing of geodetic measurements in two volumes /edited by Y. I. Markuse. Book 1. Fundamentals of the theory of errors /V. V. Golubev, Moscow: Moscow State University of Geodesy and Cartography, 2005, p. 56.

4. Belov P.V., Sirota A. I. Probability and information, M, Moscow State Institute of Radio-engineering Electronics and Automation, 2008, 48 p.

5. Klimzo B. N. Russian-English dictionary of common words and phrases scientific and technical literature. In 2 vols. - M.: ETS, 2002, v.2, p. 552.

6. GOST 27.002-89 Reliability of the technique. Basic concepts. Terms and definitions.

7. GOST 8.820-2013. ICG. Metrological support. The main provisions. 
8. International vocabulary of Metrology - Basic and general concepts and associated terms. Ed. 2, JCGM, 2010. - $82 \mathrm{p}$.

9. GOST R 54500.3-2011. (Guide ISO/IEC 98-3) The uncertainty of the measurement. Part 3 . The guide to the expression of uncertainty in measurement.

10. Galeev A. P., Nazarova G. S. Features terminology in the field of dependability, used in the national standards currently in force. Fluctuation and degradation processes in semiconductor devices: Materials of international scientific-methodical seminar, Moscow, Moscow scientific-technical society radio electronics and communications named after A. S. Popov, National Research university "MPEI", 2014, p.p. 179-182.

\title{
ПРИМЕНЕНИЕ МАШИННОГО ОБУЧЕНИЯ ДЛЯ ПОВЫШЕНИЯ ЭФФЕКТИВНОСТИ УПРАВЛЕНИЯ НЕФТЯНЫМИ СКВАЖИНАМИ
}

\author{
Аунг Зеар, \\ аспирант кафедры ПМ, \\ Михайлов И.С., \\ к.т.н., дочент кафедры ПМ \\ Нацииональный исследовательский университет «МЭИ», \\ 2. Москва, Россия,
}

\section{АННОТАЦИЯ}

В статье рассматривается применение метода интеллектуального анализа данных - машины опорных векторов (SVM) для решения практической задачи оценки эффективности нефтяных скважин. Данный нелинейный метод показывает лучшие результаты анализа чем метод линейной регрессии (LR), также являющейся методом машинного обучения. В работе приведены и проанализированы принципы решения задачи классификации с помощью методов логистической регрессии и машины опорных векторов. В экспериментах рассчитаны и сопоставлены точности этих двух алгоритмов при одинаковых условиях.

Ключевые слова: машинное обучение; интеллектуальный анализ данных; машина опорных векторов; нефтяные скважины.

\section{Введение}

Развитие цифровизации параметров работы нефтяных скважин, как источников значений параметров для массового производства, так и методов сбора данных в реальном времени, позволяет обеспечивать оптимизацию процесса добычи нефти [1]. Использование машинного обучения для очистки, интеграции, преобразования данных, разработки приложений и оптимизации анализа данных нефтяных скважин является новым научным подходом к решению задачи анализа работы нефтяных скважин. В настоящее время параметры нефтяных скважин, используемые в алгоритме анализа данных, относительно просты, при условии отсутствия параметров, зависящих от других групп параметров, и стандартных способах вычисления оценки данных [2-3]. В статье предлагается нелинейный алгоритм классификации SVM, построение структуры системы разработки данных и модели распознавания полифилетических параметров с использованием SVM через карту пространства признаков высокой размерности и оптимизированную гиперплоскостную классификацию для решения задачи анализа нелинейных параметров нефтяных сква- жин и распознавания шаблонов совокупностей значений параметров скважин, отражающих их текущее состояние.

1. Полифилетические параметры модели распознавания образов нефтяных скважин

В процессе добычи нефти центр наблюдения собирает, передает, анализирует и выдает в режиме реального времени данные о давлении, температуре, электрическом напряжении, электрическом токе и нагрузке, а также других первичных параметрах, что помогает администратору понимать условия работы нефтяной скважины и обеспечивать её работу в режиме высокой эффективности и низкого потребления [4-5]. Как правило к данным параметрам также относятся пиковые значения электрического тока и напряжения, напорное давление насоса, противодавление, давление масла и давление в затрубном пространстве скважины. Эти данные передаются в автоматизированную систему управления в режиме реального времени. После выполнения линейной аппроксимации и прогнозирования данных, лицо принимающее решение может оценивать состояние скважины в данный момент и прогнозировать её поведение в будущем, для принятия соответствующих компенсирующих управляющих воздействий. 